\title{
The Role \& Responsibility of Notaries for the Lost Minuta Due to Notary's Negligence
}

\author{
Arum Kurnia Sari ${ }^{*}$ ) and Jawade Hafidz ${ }^{* *}$ \\ ${ }^{*}$ Faculty of Law, Universitas Islam Sultan Agung (UNISSULA) Semarang, E-mail: \\ arumkurnia3@yahoo.co.id \\ ${ }^{* *}$ Faculty of Law, Universitas Islam Sultan Agung (UNISSULA) Semarang, E-mail: \\ jawade@unissula.ac.id
}

\begin{abstract}
The purpose of this research is to find out and analyze: 1). The role and responsibility of the Notary in solving the problem of the loss of the minutes of the deed due to his negligence. 2) Legal implications for a Notary who due to negligence results in the loss of the minutes of the deed. The approach method in this research is sociological juridical. The data used are primary and secondary data obtained through interviews and literature study. The technique of collecting legal materials in this research is by using observation, interview and study document techniques, while the data analysis method is done by analytical descriptive method. The results of the research concluded: 1) The role and responsibility of the Notary in solving the problem of the loss of minutes of deed due to negligence is in accordance with Article 16 paragraph (1) letter $b$ of the Notary Position Act, namely making a deed in the form of a minuta deed and storing it as part of the Notary Protocol. In resolving the loss of the minutes of the deed, one of them is to compensate the parties for losses. 2) The legal implication for a Notary who due to his negligence results in the loss of the minutes of the deed can be sanctioned, as stated in Article 9 paragraph (1) letter $d$ of the UUJN namely temporary dismissal from his position as a Notary If the Notary in making the deed is not in accordance with the laws and regulations applicable law, in this case is not in accordance with UUJN, then the act of the Notary can be qualified as a violation of the law. Unlawful Acts are regulated in Article 1365 to Article 1380 of the Civil Code that every unlawful act causes harm to another person causing the person because of his fault to make the loss to compensate for the loss.
\end{abstract}

Keywords: Minutes of Deed; Notary Negligence; Notary Responsibility.

\section{Introduction}

The notary position is an institution created by the state. Placing a Notary as a position is a field of work or task that is deliberately made by law for certain purposes and functions (certain authorities) and is sustainable as a permanent 
work environment. ${ }^{1}$ Notaries in carrying out their duties are guided by the laws and regulations which are often called the Notary Law (UUJN) Number 30 of 2004 amended by Act No. 2 of 2014. In the provisions of the Notary Regulations and the Notary Law (UUJN) basically states that the main task of a notary is to make the agreement authentic.

Errors in the notarial deed can result in the revocation of a person's rights or be pressured by someone from an obligation, therefore, a notary in carrying out his position must comply with various provisions in the Law on Notary Positions. ${ }^{2} \mathrm{An}$ agreement is said to be authentic if it is made before the competent authority. If the agreement is made in the presence of a notary, the agreement is said to be a notary agreement or an authentic agreement or notarial agreement. ${ }^{3}$ As a public official, a notary is not only involved in all actions and terms of an agreement that is required by law and by law to be an authentic deed, but a notary also has an important role in creating legal certainty for the community. ${ }^{4}$

In making a notarial agreement deed, a notary needs to pay attention to things in making an agreement, for that a notary must use the principle of prudence in making a notarial agreement deed. Notaries in making a notarial deed can minimize mistakes in the future by paying attention to things that are important in making a notarial deed. Notaries must have extensive knowledge of the agreement in order to make a deed of agreement in any form. ${ }^{5}$ Authentic deeds can be used as written evidence, the strongest and fulfilled in trials and dispute resolutions that occur. And a Notary must be able to provide legal certainty for the public who use Notary services. ${ }^{6}$

Notary products in the form of authentic deeds are real actions that are subject to the provisions of civil law, especially the law of evidence. If the requirements as an authentic deed are in accordance with what has been required as a national administrative decision that is specific, personal, final, and the deed made before a Notary is not the will of the Notary, but the deed is made or formulated according to the wishes or wishes of the parties. ${ }^{7}$ If it turns out that at a later date in carrying out their duties and authorities regarding each agreement and determination, problems/disputes occur, either the fault of the Notary or the fault of the parties. If an error occurs due to a notary error, either because

1 D Saputra, Sri Endah Wahyuningsih, 2017, Prinsip Kehati-Hatian Bagi Notaris/Ppat Dalam Menjalankan Tupoksinya Dalam Upaya Pencegahan Kriminalisasi Berdasarkan Kode Etik, Jurnal Akta, p. 348.

${ }^{2}$ Abdul Ghofur Anshori, 2009, Lembaga Kenotariatan Indonesia, Perspektif Hukum dan Etika, UII Press,Yogyakarta, p. 46

${ }^{3}$ A. Kohar, 1983, Notaris Dalam Praktek Hukum, Alumni, Bandung, p. 64

${ }^{4}$ Abintoro Prakoso, 2015, Etika Profesi Hukum, Laksbang Justitia, Surabaya, p.125.

5 Y Hanapiah, Wahyuningsih, 2018, Hal-Hal Yang Perlu Diperhatikan Oleh Notaris Dalam Membuat Akta Perjanjian Notariil, Jurnal Akta, p. 116.

${ }^{6}$ H. Salim. Hs Dan H. Abdullah, 2007, Perancangan Kontrak Dan Mou, Sinar Grafika, Jakarta, p.102.

${ }^{7}$ Habib Adjie, 2008, Sanksi Perdata Dan Administratif Terhadap Notaris Sebagai Pejabat Publik, Refika Aditama, Bandung, p.15. 
the notary is negligent or because the notary is intentionally doing it, the notary must be able to take responsibility. ${ }^{8}$

Another responsibility of a Notary as the party authorized to make an authentic deed is to keep the minutes of the deed as referred to in Article 16 paragraph (1) of Act No. 2 of 2014 concerning Amendments to Act No. 30 of 2004 concerning Notary Positions (UUJN). In letter b of Article 16 paragraph (1) it is stated that a Notary is obliged to make a Deed in the form of a Minute Deed and keep it as part of the Notary Protocol. This is because the Notary Protocol is a collection of documents which are state archives that must be stored and maintained by a Notary as stated in Article 1 number 13 of the UUJN.

The implication of the Notary's obligation to maintain the minutes of the deed is that if the minutes of the deed are lost due to his carelessness or his employees, it can be said that the Notary has not carried out his obligations in storing the minutes of the deed correctly. Notaries should be more careful and careful in storing, especially the minutes of the deed, because if the minutes of the deed have not been found when the minutes of the deed are needed and it has not been found, this can harm the client, the Notary can be prosecuted legally. For this the party who suffers losses as a result of unlawful acts committed by the Notary, namely by not keeping the minutes of the deed from the deed he made, has not received legal protection. Notaries who do not carry out these obligations as stated in Article 16 paragraph (11) letters a to letter I of the UUJN may be subject to sanctions ranging from written warnings to dishonorable dismissals. However, of course, every violation of the law must follow the steps of the procedures that have been set.

Based on this background, the title was appointed: ""Role and Responsibilities of Notaries Against Loss of Minutes of Deed Due to Negligence of a Notary in Semarang City." This research seeks to answer the problem of the role and responsibility of the Notary in solving the problem of the loss of the minutes of the deed due to his negligence, as well as the legal implications for the Notary who due to his negligence resulted in the loss of the minutes of the deed.

\section{Research Methods}

The approach method used in this research is sociological juridical, namely researching and studying law as a law in action study because it studies and examines the interrelationships between law and other social institutions. Law in action law studies are non-doctrinal and empirical social studies. ${ }^{9}$ The data

\footnotetext{
${ }^{8}$ Habib Adjie (A), 2008, Hukum Notaris Di Indonesia Tafsir Terhadap Tematik Undang- Undang Nomor 30 Tahun 2004 Tentang Jabatan Notaris, Bandung, p.24.

${ }^{9}$ Ronny Hanitijo Soemitro, 1988, Metodologi Penelitian Hukum Dan Jurimetri, Ghalia Indonesia, p. 34
} 
used are primary and secondary data obtained through interviews and literature study. The technique of collecting legal materials in this research is by using observation, interview and study document techniques, while the data analysis method is done by analytical descriptive method.

\section{Results and Discussion}

\subsection{The Role and Responsibilities of a Notary in Resolving the problem of the loss of the minutes of the deed due to his negligence}

Notaries in carrying out their positions must act as guides in the field of law and can provide useful instructions for people who have an interest in them. Notaries are not subject to a provision from the authorities regarding civil servants, however, incarry out In his position, a notary must always be based on a high moral integrity and honesty, because the deeds made by a notary are state documents that must be maintained and are very important in the application of the law of proof, namely as authentic evidence concerning the interests of justice seekers. A notary is usually considered an official from whom one can obtain reliable advice. Everything written and established is true. Notaries are strong document makers in a legal process. ${ }^{10}$

The definition of a responsibility is the state of being obliged to bear everything if something happens then someone may be prosecuted, blamed, sued. As far as possible, the notary must try to find out that the identities and statements of the parties are true. The notary can obtain these information from people he knows and trusts or can see proof of identity from the parties, but if it turns out that all the information given by the parties is not true, then all of that is not the responsibility of the notary because the notary only responsible for the formal truth that has been given by the parties. ${ }^{11}$

The ethical responsibility of a notary is related to moral norms which are a measure for a notary to determine the right or wrong or the good or bad of the actions taken in carrying out his profession. This responsibility includes 3 (three) things, namely: ${ }^{12}$

a. When the action is carried out in a state of normal ability of reason.

b. In the event that a notary commits a violation with free will.

\footnotetext{
${ }^{10}$ Tan Thong Kie, 2001, Serba Serbi Praktek Notaris, Ichtiar Baru, Jakarta, p.30

${ }^{11}$ Muhammad Ali, Op. Cit., p.139

12 Sarihartati, 2018, Peranan Notaris Dalam Memberikan Perlindungan Hukum Terhadap Pembeli Tanah Kaveling Yang Belum Bersertifikat, Jurnal Universitas Sumatera Utara, Medan, H.90
} 
c. The existence of a notary with malicious intent and as a result causes losses.

In essence, morality is closely related to ethics, which has 2 (two) meanings. First, as a collection of judgments about actionsman. Second, it is ethical which is used for human actions regarding ethical values and norms that are moral and must be supported by high moral integrity. This is stated in the regulations for the position of a notary.

Determining the existence of a civil or criminal liability committed by a notary must fulfill three conditions, namely that there must be a punishable notary act whose elements are expressly formulated by law. The notary's actions are against the law, and there must be an error on the part of the notary. Errors or omissions in the criminal sense include elements contrary to the law and there must be an unlawful act. So that basically every form of violation or negligence committed by a notary always contains an unlawful nature in the act.

The responsibilities of a notary in the UUJN are contained in Article 65 of the UUJN, where it is stated that "a notary, a substitute notary, a special substitute notary, and a temporary official notary are responsible for every deed he makes though the notary protocol has been submitted or transferred to the custodian of the notary protocol." ${ }^{13}$ Looking at the formulation of the article, it is known that the notary still has to be responsible for every deed he made even though the notary protocol has been submitted or transferred to the notary protocol custodian.

One of the obligations of a Notary that must always be carried out is stated in Article 16 paragraph (1) letter $b$ that the notary must make a deed in the form of a minutes of deed and save it as a notary protocol. The minutes of the deed are the state archives which one day will be needed if there is a case in the future. Although the deed made by a notary varies and even there are many, the minutes of the deed must be kept. Minutes of deed or minutes is the original deed signed by the appearers, witnesses and notaries and stored in the archives of a notary (not a copy or quote and also not grosse). All minutes of deed, repertoire and klapper must be kept by a notary because they are all important documents that must be archived and kept by a notary. ${ }^{14}$

\footnotetext{
${ }^{13}$ Article 65 of Act No. 2 of 2014 concerning Amendments to Act No. 30 of 2004 concerning the Position of a Notary

${ }^{14}$ Budiono, Herlien. 2013, Dasar Teknik Pembuatan Akta Notaris, Citra Adiyta Bakti, Bandung, p. 81
} 
Prior to the issuance of a copy, the minutes of the deed are made with complete initials and signatures of all parties, witnesses and notaries. In making a copy of the deed must be guided by the minutes of the deed. A copy of the deed exists after the minutes of the deed are made by the Notary. What is meant by the copy of the deed listed in Article 1 is a verbatim copy of the entire deed and at the bottom of the copy of the deed the phrase "given as a copy with the same sound". In the copy of the deed there is a notary statement starting from the beginning of the deed and the end of the deed. The beginning of the deed explains that the parties have appeared before the Notary and at the end of the deed there is information regarding the minutes of the deed that has been signed perfectly and as a copy of the same sound. The meaning of the same sound is that the copy of the deed is exactly the same as the minutes of the deed. Notaries should be more careful and careful to save especially the minutes of deeds, so that the minutes of deeds that have not been found and because of the carelessness of their employees can be more vigilant and extra careful in storing them and the notary can be said to be negligent due to the actions of his employees who cannot save the minutes the. One example is that when the minutes of the deed were needed, it turned out that it had not been found and could harm the client if something unexpected happened. So that the minutes of the deed that have not been found and because of the carelessness of the employees can be more vigilant and extra careful in storing it and the notary can be said to be negligent due to the actions of his employees who cannot keep the minutes. One example is that when the minutes of the deed were needed, it turned out that they had not been found and could harm the client if something unexpected happened. ${ }^{15}$

In terms of the theory of authority, authority is the freedom to do or not to take certain actions or to demand other parties to perform certain actions, while obligations contain the obligation to do or not to take certain actions. ${ }^{16}$ Authority is not the same as power, its power describes the right to do or not to do. In law, authority simultaneously means rights and obligations. The position of a notary that is noble and dignified is expected to provide legal certainty with the deed he made, the authority and obligations that are always carried out. The role and responsibility of the Notary in making the minutes of the deed and keeping the minutes of the deed as a notary protocol must always be carried out. Considering the importance of Article 16 paragraph 1 (one) letter $b$ where the Notary must make the minutes of the deed and keep the minutes of the deed as a notary protocol.

The legal authority for Notaries is stated in Article 15 paragraph (1) of Act No. 02 of 2014 concerning Notary Positions which are related to the obligations of

\footnotetext{
${ }^{15} \mathrm{Ibid}$

${ }^{16}$ Ridwan H.R, 2006, Hukum Administrasi Negara, Raja Grafindo Persada, Jakarta, p. 102
} 
Article 16 paragraph (1) letter b of Act No. 02 of 2014 concerning Notary Positions to keep the minutes of the deed as a protocol. Notary Public. If the minutes of the deed are not made and not saved, then the Notary has violated the provisions causing no legal certainty for the deed he made because it is clear that in making the deed the Notary did not fulfill the formal aspects of the authentic deed. Such actions are contrary to the obligations of the Notary in carrying out his duties. Meanwhile, if viewed from the theory of legal certainty, legal certainty requires efforts to regulate law in legislation made by authorized and authoritative parties. ${ }^{17}$

Notaries are public officials authorized to make authentic deeds and other authorities regulated in the Law on Notary Positions. Where the authentic deed is evidence that has perfect and absolute evidentiary power for the parties to the agreement, especially in the event of a dispute so as to create legal certainty.

The law is in charge of ensuring legal certainty (rechszekerheid) in the association in that task, two other tasks are concluded, namely to ensure justice and the law remains useful, and the third task is concluded, namely the law to protect society from taking vigilante (eigenrichting). The role of a notary as a public official must always follow legal developments to people in need and maintain the deeds he made to always be able to provide legal certainty. This is also because the notary can keep the minutes of his deed well, the community is increasingly aware of the importance of agreements or legal relationships made by the parties as outlined in an authentic deed with the aim of ensuring legal certainty and can be used as perfect evidence.

\subsection{Legal Implications for Notaries who due to Negligence Result in Loss of Minutes of Deed}

A Notary in carrying out his position must remember that the deed made by or before him is an Authentic Deed. The Authentic Deed is in the form of a Minute Deed which becomes a State Document/Archive and the agreement stated therein becomes law for those who make it, so in accordance with Articles 1337 BW and 1338 BW Notaries are also public officials who have the authority with exceptions. Public here means law, not general. Notaries are also public officials who are partially authorized by the power of the State to produce written and authentic evidence in matters of civil law. Notary is not a structural position in the government, but his authority is specifically attached to his position. Notary

${ }^{17}$ Asikin zainal, 2012, Pengantar Tata Hukum Indonesia, Rajawali Press, Jakarta, p. 1 
authority is obtained by attribution because Notaries are appointed based on the Law on Notary Positions.

The notary has an obligation to make a deed at the request or desire of the appearers, so in this case it provides a basis for the notary and the parties there has been a legal relationship. Therefore, the Notary must ensure that the deed made is in accordance with the prescribed legal rules, so that the interests concerned are protected by the deed. If the Notary in making the deed is not in accordance with the applicable laws and regulations, in this case it is not in accordance with the UUJN, then the Notary's actions can be qualified as unlawful acts. Unlawful Acts are regulated in Article 1365 to Article 1380 of the Civil Code. Article 1365 states, $^{18}$

Acts against the law as described above have an impact on the emergence of legal consequences. Legal consequences are consequences given by law on an act of a legal subject. In this regard, Ahmad Ali classifies legal consequences into 3 types, namely as follows:

a. Legal consequences in the form of the birth, change, or disappearance of a certain legal rule.

b. Legal consequences in the form of birth, change, or disappearance of a certain legal relationship.

c. The legal consequences are in the form of sanctions, both criminal sanctions and sanctions in the field of civil law.

Meanwhile, in the field of civil law, sanctions are known for both unlawful acts and defaults. For acts against the law, the sanction is the provision of compensation based on Article 1365 of the Civil Code.

In UUJN Article 16 paragraph (1) letter $b$ which regulates the obligation of a Notary to make a deed in the form of a minuta deed and keep it as part of the Notary Protocol. Based on the foregoing, a Notary who does not comply with or does not carry out his obligations in accordance with the provisions of the UUJN, in this case is a Notary who cannot make and keep the minutes of his deed as part of the Notary protocol, as stated in Article 16 paragraph (1) letter b UUJN, then it can be categorized as an act that violates the law.

The loss of the minutes of deed is caused by several factors, one of which is the busyness of the Notary concerned, so that the minutes of the deed are not

18 Lely, Analisis Yuridis Terhadap Kelalaian Notaris Dalam Penyimpanan Minuta Akta, Jurnal Hukum, Fakultas Kenotariatan Universitas Brawijaya, Malang, p.8 
saved at the same time. If it is reviewed based on the reasons as referred to above, according to the author, basically the Notary has no intention of not keeping the minutes of deed immediately after issuing a copy of the minutes of the deed, but because of the busyness of the Notary, he may have to accept several clients at that time.

Errors like this are classified as errors caused by negligence on the part of the Notary. There is a Loss for the Parties Compensation is a favor received by taking into account the damage suffered, and the loss must be measured in money. If the matter is related to an infringement, compensation is something that is given to the party who suffered the loss commensurate with the calculation of the damage suffered. ${ }^{19}$

Theoretically, it is said that a claim for compensation based on reasons for violating the law can only be carried out if it meets the four elements below, namely there is an unlawful act, there is a loss, there is an error, there is a causal relationship between the loss and the unlawful act. The legal consequences arising from such unlawful acts can occur in 2 (two) things, namely:

\section{1) Legal Consequences for Notaries}

The legal consequences that arise against a Notary who does not keep or delete the minutes of the deed is that the Notary may be subject to sanctions, as stated in Article 9 paragraph (1) letter $d$ of the UUJN, namely temporary dismissal from his position as a Notary because he has violated his obligations and prohibited his position. . However, in this case the Notary has died, then this sanction can no longer be implemented because it is impossible for the sanction to be imposed on the perpetrator who has died.

\section{2) Legal Consequences on Deeds}

According to Sudikno Merokusumo, a deed is a letter as evidence that is signed and contains events that form the basis of a right or an engagement, which was made from the beginning intentionally for proof. Proof is one step in the civil case process. Proof is needed because of a rebuttal or denial from the opposing party or to justify a right that is in dispute. ${ }^{20}$ That written evidence in civil cases is the main evidence, because in civil traffic, people often intentionally provide

\footnotetext{
${ }^{19} \mathrm{Ibid}$

${ }^{20}$ Sudikno Mertokusumo,1981, Hukum Acara Perdata di Indonesia, Liberty, Yogyakarta, p.149
} 
evidence that can be used if a dispute arises, and this evidence is usually in the form of writing. ${ }^{21}$

The above applies to the minutes of the deed that are lost or not kept by the retired Notary, while the act of not keeping the minutes of the deed carried out by the Notary giving the protocol who has died, according to the author of the minutes of the deed, if no one wants to keep it for as the protocol will be kept by the Regional Supervisory Council. Notaries are very important to help people's lives who need written evidence. With regard to written evidence, it can be seen in Article 1867 of the Civil Code that written evidence must be carried out in authentic writings or written under hand. The deed under the hand is made in free form and not before a public official.

\section{Conclusion}

1) The Role and Responsibilities of a Notary in Resolving the problem of the loss of minutes of deed due to negligence is in accordance with Article 16 paragraph (1) letter $b$ of the Notary Position Act, namely making a deed in the form of a minuta deed and storing it as part of the Notary Protocol. As for responsibility one of the notaries in resolving the loss of the minutes of the deed is to compensate the parties, if the parties are harmed by the notary concerned. Meanwhile, sanctions for notaries who are negligent in keeping the minutes of the deed made may be subject to sanctions in the form of verbal warnings, written warnings, temporary dismissals, respectful dismissals and dishonorable discharges. 2) The legal implications for a Notary who because of his negligence resulted in the loss of the minutes of the deed, namely: Notaries who do not keep or delete the minutes of the deed may be subject to sanctions, as stated in Article 9 paragraph (1) letter $d$ of the UUJN, namely temporary dismissal from their position as a Notary because they have violated their obligations and prohibited positions. A Notary in carrying out his position must remember that the deed made by or before him is an Authentic Deed. If the Notary in making the deed is not in accordance with the applicable laws and regulations, in this case it is not in accordance with the UUJN, then the Notary's actions can be qualified as unlawful acts. Unlawful Acts are regulated in Article 1365 to Article 1380 of the Civil Code. Article 1365 states that any unlawful act that causes

\footnotetext{
${ }^{21}$ Darwan Prinst, 2002, Strategi Menyusun dan Menangani Gugatan Perdata, Citra Aditya Bakti, Bandung, p. 157
} 
harm to another person causes the person to make the mistake of issuing the loss to compensate for the loss.

\section{References}

[1] Abdul Ghofur Anshori, 2009, Lembaga Kenotariatan Indonesia, Perspektif Hukum dan Etika, UII Press,Yogyakarta

[2] Abintoro Prakoso, 2015, Etika Profesi Hukum, Laksbang Justitia, Surabaya

[3] Asikin zainal, 2012, Pengantar Tata Hukum Indonesia, Rajawali Press, Jakarta

[4] Budiono, Herlien. 2013, Dasar Teknik Pembuatan Akta Notaris, Citra Adiyta Bakti, Bandung

[5] D Saputra, Se Wahyuningsih, 2017, Prinsip Kehati-Hatian Bagi Notaris/Ppat Dalam Menjalankan Tupoksinya Dalam Upaya Pencegahan Kriminalisasi Berdasarkan Kode Etik, Jurnal Akta

[6] Darwan Prinst, 2002, Strategi Menyusun dan Menangani Gugatan Perdata, Citra Aditya Bakti, Bandung

[7] H. Salim. Hs Dan H. Abdullah, 2007, Perancangan Kontrak Dan Mou, Sinar Grafika, Jakarta

[8] Habib Adjie (A), 2008, Hukum Notaris Di Indonesia Tafsir Terhadap Tematik Undang- Undang Nomor 30 Tahun 2004 Tentang Jabatan Notaris, Bandung

[9] Habib Adjie, 2008, Sanksi Perdata Dan Administratif Terhadap Notaris Sebagai Pejabat Publik, Refika Aditama, Bandung

[10] A. Kohar, 1983, Notaris Dalam Praktek Hukum, Alumni, Bandung

[11] Lely, Analisis Yuridis Terhadap Kelalaian Notaris Dalam Penyimpanan Minuta Akta, Jurnal Hukum, Fakultas Kenotariatan Universitas Brawijaya, Malang

[12] Mulyoto, 2014, PertanggungJawaban Notaris-PPAT Dalam Menjelankan Tugas Jabatannya, Cakrawala Media, Yogyakarta

[13] Ridwan H.R, 2006, Hukum Administrasi Negara, Raja Grafindo Persada, Jakarta

[14] Ronny Hanitijo Soemitro, 1988, Metodologi Penelitian Hukum Dan Jurimetri, Ghalia Indonesia

[15] Sarihartati, 2018, Peranan Notaris Dalam Memberikan Perlindungan Hukum Terhadap Pembeli Tanah Kaveling Yang Belum Bersertifikat, Jurnal Universitas Sumatera Utara, Medan

[16] Sudikno Mertokusumo,1981, Hukum Acara Perdata di Indonesia, Liberty, Yogyakarta 
[17] Tan Thong Kie, 2001, Serba Serbi Praktek Notaris, Ichtiar Baru, Jakarta

[18] Y Hanapiah, Wahyuningsih, 2018, Hal-Hal Yang Perlu Diperhatikan Oleh Notaris Dalam Membuat Akta Perjanjian Notariil, Jurnal Akta 